\title{
Do results of the recruitment of candidates for a bachelor's degree course in nursing correctly predict the level of social skills of a graduate? Preliminary study
}

\section{Czy wyniki kwalifikacji kandydatów na studia pielęgniarskie pierwszego stopnia trafnie przewiduja poziom kompetencji społecznych absolwentów? Badanie wstępne}

\author{
Mariusz Panczyk ${ }^{1}$, Zofia Sienkiewicz², Paweł Zegarow², Joanna Gotlib ${ }^{1}$ \\ ${ }^{1}$ Division of Teaching and Outcomes of Education, Faculty of Health Science, Medical University of Warsaw, Poland \\ Head of the Division: Joanna Gotlib PhD, Assoc. Prof. \\ ${ }^{2}$ Division of Community Nursing, Faculty of Health Science, Medical University of Warsaw, Poland \\ Head of the Division: Jacek Imiela PhD, Assoc. Prof.
}

Key words: social skills, school admission criteria, psychometrics, questionnaires.

Słowa kluczowe: umiejętności społeczne, kryteria przyjęcia na studia, psychometria, kwestionariusze.

\begin{abstract}
Introduction: For several years we have seen growing interest of the role social skills of nurses in efficient and safe patient care. Aim of the research: To evaluate to what extent the results of the recruitment of candidates for a bachelor's degree course in nursing correlate with a social skills profile evaluated at the end of the course.

Material and methods: A total of 113 graduates from the Medical University of Warsaw were involved in the study. The analysis concerned data on the admission procedure, namely the matura exam (secondary school exit exam) results in Polish, foreign language, and an additional subject. A standardised PROKOS questionnaire that permits the measurement of psychometrics in five specific scopes was used to assess the social skills profile of the graduates. Non-parametric Spearman's correlation $\left(r_{s}\right)$ was used in the study, and calculations were performed using Statistica 12.5 software.

Results: Exam results in Polish were positively correlated with the level of assertive $\left(r_{s}=0.23\right)$ and community-focused $\left(r_{\mathrm{s}}=0.21\right)$ skills. Moreover, the level of social skills depended significantly on the matura exam results in an additional subject $\left(r_{s}=0.21\right)$. A correlation between age at admission and the scope of cooperative skills $\left(r_{s}=0.17\right)$ was also observed. However, neither of the domains of the profile was related significantly with ranking scores for a foreign language.

Conclusions: Admission criteria used in the selection procedure for nursing insufficiently predicted the level of future social skills of graduates. It is recommended to introduce an assessment of non-cognitive skills at the stage of recruiting candidates to increase the validity of the admission procedure.
\end{abstract}

\section{Streszczenie}

Wprowadzenie: Od kilku lat obserwujemy wzrost zainteresowania rolą kompetencji społecznych pielęgniarek w efektywnej i bezpiecznej opiece nad pacjentami.

Cel pracy: Próba odpowiedzi na pytanie, w jakim stopniu wyniki kwalifikacji kandydatów na studia pielęgniarskie pierwszego stopnia są skorelowane z profilem kompetencji społecznych ocenianym pod koniec studiów.

Materiał i metody: Badano łącznie 113 absolwentów Warszawskiego Uniwersytetu Medycznego. Analizowano dane dotyczące kwalifikacji na studia, które obejmowały wyniki egzaminu maturalnego z języka polskiego, języka obcego oraz przedmiotu dodatkowego. Profil kompetencji społecznych oceniano za pomoca standaryzowanego kwestionariusza PROKOS, który umożliwia pomiar psychometryczny w pięciu wymiarach. W badaniu wykorzystano nieparametryczną korelację $r$-Spearmana $\left(r_{s}\right)$, a obliczeń dokonano z użyciem programu Statistica wersja 12.5.

Wyniki: Wyniki kwalifikacji z języka polskiego były pozytywnie skorelowane z poziomem asertywności $(r=0,23)$ oraz kompetencjami społecznymi $\left(r_{s}=0,21\right)$. Ponadto poziom kompetencji społecznych istotnie zależał od wyników maturalnych z przedmiotu dodatkowego $\left(r_{\mathrm{s}}=0,21\right)$. Wiek $\mathrm{w}$ chwili przyjęcia na studia wiązał się z kompetencjami w zakresie współpracy $\left(r_{s}=0,17\right)$. Żadna domena ocenianego profilu nie była istotnie związana z punktacją z języka obcego. 
Wnioski: Kryteria kwalifikacyjne stosowane podczas naboru na studia pielęgniarskie w niedostatecznym stopniu przewidywały poziom kompetencji społecznych absolwentów tego kierunku. Rekomenduje się wprowadzenie na etapie przyjmowania kandydatów na studia oceny kompetencji z domeny pozapoznawczej (non-cognitive) w celu zwiększenia trafności procesu kwalifikacji.

\section{Introduction}

Social skills are a complex scope of abilities that enable individuals to undertake activities in order to deal with certain situations [1]. Robert White defined social skills for the first time in 1959 as "specific human skills contributing to the effective interaction with the environment" [2]. Therefore, individuals need to develop different abilities in order to be capable of functioning effectively in diverse social conditions in the workplace. Social skills are not the same as social intelligence, and a proper level of skills in this area may be reached either through social training or an appropriately managed teaching process at university [3].

The need to cooperate with people of different skills, mentality, and values as well as, in particular, teamwork makes the quality of care provided by nurses heavily dependent on the level of their social skills [4]. The needs of the labour market with respect to ability to deal with e.g. interpersonal relationships, giving instructions, expressing disapproval, communicating massages that could be unpleasant to others, or initiating and meeting social aims are reflected in the requirements stated in the present teaching standards for nursing students. There are 10 scopes of social skills stated in the teaching standards for bachelor's degree programme [5]. A curriculum for the Nursing programme includes the above-mentioned teaching outcomes because effective work not only requires appropriate intellectual potential and "hard" skills but also the ability to function in the social environment: establishing and maintaining interpersonal relationships, cooperating and communicating with others, influencing others effectively, and resisting the influence of other people, if necessary [6-8].

The existing scientific data on predictive assessment of success factors for nursing students both at university and in their professional life demonstrate a key role of features that are not a part of the purely cognitive domain (so-called non-cognitive qualities, personal qualities, personal attributes, personal characteristics, and non-academic factors) [9]. However, not much is known about effective assessment of these kinds of features in the admission process for candidates for nursing [10]. A growing problem of the lack of empathy and improper behaviour of nurses towards patients and their family members has been noticed. This may be a result of improper preparation of graduates for the profession regarding social skills [9, 11-13]. Due to the factors mentioned above it is necessary to monitor and supervise the influence of variables that are not directly associated with the level of academic preparation for studies or students' educational progress but are a part of the above-mentioned non-cognitive elements significantly influencing the quality of education.

The present admission procedure for candidates for a bachelor's degree programme in nursing at the Medical University of Warsaw or any other university-level school in Poland does not evaluate initial social skills at admission. All criteria used in the recruitment process are associated only with the cognitive domain and refer to the assessment of knowledge and skills regarding one or several matura subjects [14]. Therefore, there is a need to estimate to what extent the present selection methods reflect future achievements of students with respect to social skills assessed at the end of the programme [9].

\section{Aim of the research}

The present study aimed to assess the correlation between the results of the recruitment of candidates for a bachelor's degree course in nursing and particular scopes of the social skills profile evaluated the end of the course.

\section{Material and methods}

The study involved a total of 113 graduates from the Faculty of Health Sciences, Medical University of Warsaw, who completed a full-time bachelor's degree programme in nursing in 2015 . This group constituted $82.7 \%$ of all nursing graduates at that time. Women tended to predominate among the study group (95.7\%) as well as persons who graduated from secondary schools outside Warsaw (73.9\%). The mean age of students in the year of starting studies amounted to $19.7 \pm 2.54$ years (median: 19.0; coefficient of variation: $12.8 \%$ ), and at the time of graduating from the programme it was $22.7 \pm 2.34$ years (median: 22.0; coefficient of variation: $10.3 \%$ ).

The authors sought advice from the Bioethics Committee of the Medical University of Warsaw to conduct the presented study. Because the "commission does not issue opinions on the survey, retrospective and other non-invasive scientific studies", approval was not required. Detailed information and model documents of the Ethical Review Board of Warsaw Medical University are available at: https://komisja-bioetyczna. MUW.edu.pl/content/szczegółowe-informacje-oraz-wzorydokumentów (date of access: April 7, 2016). Participation in the survey was voluntary, and the attendees were informed about the purpose and manner of conducting the study. The participants expressed their verbal 
agreement to contribute in the study. Each participant had the opportunity to familiarise themselves with the level of their social skills and consult with a psychologist. Raw data were encoded and sent to the statistical analysis of preventing the identification of individual participants. Those directly involved in the preparation and conduct of the studies obtained approval of the Local Controller of Personal Data for processing of personal data of Medical University of Warsaw students.

Data concerning the admission procedure were obtained on the basis of information provided by candidates in the application forms. The results were taken from the University Admissions Office and included the ranking scores with reference to three criteria: Polish, foreign language, and selected additional subject.

The social skills profile of graduates was assessed using a standardised self-reported PROKOS questionnaire that measures psychometrics in five specific scopes: assertive skills (scale A), cooperative skills (scale K), sociable skills (scale T), social resourcefulness (scale Z), and community-focused skills (scale S) [8]. The questionnaire contained 60 diagnostic items (concerning social skills) and 30 buffer items (regarding skills other than social). Each item in the questionnaire took into account situations and actions that are possible in adult life divided into three areas of social activity: working life, social and family life, as well as social activity and management of everyday personal issues [7]. Each study participant assessed how well he or she deals with (or would deal with) particular situations using a fourlevel scale (very well, rather well, rather poorly, very poorly). A normalisation study and a study of psychometric characteristics conducted by the authors of the PROKOS questionnaire confirmed its usefulness in assessment of the social skills profile of adults [8].

\section{Statistical analysis}

Non-parametric Spearman coefficient of rank correlation $\left(r_{s}\right)$ was used to calculate correlations between age, ranking scores obtained in the admission process for three subject criteria, and the level of skills for particular elements of the profile. Moreover, KruskalWallis ANOVA rank test was used to assess potential differences in the level of final social skills observed in graduates by a selected additional subject (biology or chemistry/mathematics/other subject). Statistica statistical package version 12.5 (StatSoft, Inc.) licensed to Medical University of Warsaw was used in the analysis. The a priori significance level was established for all analyses at $\alpha<0.05$.

\section{Results}

The results of the study of the social skills profile of graduates demonstrated low and very low levels of those skills in all of the five domains (Table 1). As many as $73.5 \%$ of the students graduating in 2015 received a very low summative score on the PROKOS scale. Furthermore, on the basis of the norms used for the assessment of the questionnaire results, it was observed that, in general, the study group had the poorest results regarding cooperative skills and social resourcefulness and the best results with respect to community-focused skills.

A correlation analysis demonstrated that the level of cooperative skills measured at the end of the studies grew with the age of candidates $\left(r_{s}=0.17\right)$. Positive correlations were also observed in the case of exam results in Polish, which was highly dependent on the level of initial assertive $\left(r_{s}=0.23\right)$ and communityfocused skills $\left(r_{s}=0.21\right)$. What is more, there was a significant correlation between the level of sociable skills and the matura exam results in an additional subject $\left(r_{s}=0.21\right)$. However, no correlations between any of the domains of the social skills profile and the results of the matura exam in a foreign language were found. See Table 2 for a list of all values of Spearman coefficients of rank correlations.

Table 1. List of parameters of descriptive statistics and frequency of particular levels of social skills among the study group of graduates

\begin{tabular}{|c|c|c|c|c|c|c|c|c|c|c|}
\hline \multirow[t]{2}{*}{$\begin{array}{l}\text { PROKOS } \\
\text { questionnaire }\end{array}$} & \multicolumn{3}{|c|}{$\begin{array}{c}\text { Parameters } \\
\text { of descriptive statistics }\end{array}$} & \multicolumn{7}{|c|}{ Level of skills } \\
\hline & Mean & Median & SD & Very low & Low & Lowered & Average & Increased & High & Very high \\
\hline Subscale (A) & 29.9 & 30.0 & 6.05 & 21 & 50 & 22 & 18 & 2 & - & - \\
\hline Subscale (K) & 27.7 & 28.0 & 5.57 & 111 & 2 & - & - & - & - & - \\
\hline Subscale (T) & 22.1 & 22.0 & 5.88 & 37 & 46 & 16 & 12 & 2 & - & - \\
\hline Subscale (Z) & 22.9 & 23.0 & 4.94 & 99 & 13 & 1 & - & - & - & - \\
\hline Subscale (S) & 12.6 & 13.0 & 3.11 & 12 & 26 & 30 & 41 & 3 & 1 & - \\
\hline Summative scale & 115.1 & 118.0 & 22.62 & 83 & 27 & 2 & 1 & - & - & - \\
\hline
\end{tabular}

$A$-assertive skills, $K$ - cooperative skills, $T$ - sociable skills, $Z$ - social resourcefulness, $S$ - community-focused skills, SD - standard deviation. 
Table 2. Values of Spearman coefficients of rank correlations defining correlations between age and admission criteria and scores for particular subscales of the PROKOS questionnaire

\begin{tabular}{|lcccc|}
\hline PROKOS & \multicolumn{3}{c}{ Ranking scores } & $\begin{array}{c}\text { Age in the year } \\
\text { of starting studies }\end{array}$ \\
\cline { 2 - 4 } questionnaire & Polish language & Additional subject* & Foreign language & 0.03 \\
Subscale (A) & $0.23^{\star *}$ & 0.16 & 0.05 & $0.17^{\star *}$ \\
Subscale (K) & 0.09 & -0.06 & -0.02 & 0.05 \\
Subscale (T) & 0.08 & $0.21^{\star *}$ & 0.04 & -0.04 \\
Subscale (Z) & 0.15 & 0.03 & 0.01 & 0.03 \\
Subscale (S) & $0.21^{* *}$ & 0.12 & 0.06 & 0.05 \\
\hline Summative scale & 0.16 & 0.12 & 0.01 & \\
\hline
\end{tabular}

A - assertive skills, $K$ - cooperative skills, $T$ - sociable skills, $Z$ - social resourcefulness, $S$-community-focused skills, *biology, chemistry, mathematics, civics, history, geography, ${ }^{\star *} p<0.05$.

Table 3. Comparison of values of mean ranks for particular subscales of the PROKOS questionnaire by a selected additional subject

\begin{tabular}{|c|c|c|c|c|c|}
\hline \multirow{2}{*}{$\begin{array}{l}\text { PROKOS } \\
\text { questionnaire }\end{array}$} & \multicolumn{3}{|c|}{ Selected additional subject } & \multirow[t]{2}{*}{$H$} & \multirow[t]{2}{*}{$P$-value ** } \\
\hline & $\begin{array}{l}\text { Biology or } \\
\text { chemistry }\end{array}$ & Mathematics & Other* & & \\
\hline Subscale (A) & 54.72 & 56.41 & 50.36 & 0.2589 & 0.8786 \\
\hline Subscale (K) & 55.88 & 53.96 & 68.86 & 1.4000 & 0.4966 \\
\hline Subscale $(T)$ & 57.81 & 55.80 & 41.36 & 1.5654 & 0.4572 \\
\hline Subscale (Z) & 53.28 & 55.86 & 62.79 & 0.5413 & 0.7629 \\
\hline Subscale (S) & 57.99 & 55.41 & 44.29 & 1.0834 & 0.5817 \\
\hline Summative scale & 55.29 & 56.04 & 51.14 & 0.1521 & 0.9268 \\
\hline
\end{tabular}

$A$ - assertive skills, $K$ - cooperative skills, $T$ - sociable skills, $Z$ - social resourcefulness, $S$ - community-focused skills, *civics, history, geography, ${ }^{* *}$ Kruskal-Wallis ANOVA rank test.

A comparison of the influence of an additional subject selected by the candidate (biology or chemistry/mathematics/other subjects) on the level of social skills evaluated at the end of studies did not show any statistically significant correlations (Table 3).

\section{Discussion}

Despite a long history of studies of social skills, only over the last two decades, interest in the issue has increased significantly. Increased awareness of the role of these skills in effective human functioning, particularly at work, has been observed [8]. Attention has also been drawn to the possibility of improving "soft" skills through the introduction of appropriate training programmes [15]. In the context of training prospective nurses, it has been seen that greater focus had been put on proper professional preparation that should include not only "hard" skills, but also those skills that refer to the ability to communicate with others, cooperate with others, exert influence on others, or "efficient self-management" in different social situations [16-20]. With the evolution of the nursing profession, the changing role of nurses, and the scope of their rights and duties, it has become necessary to train in new skills that are required from graduates in nursing [20]. They include, among others, the following: (I) the ability to communicate with therapy team members, patients, and their families [21]; (II) leadership and conflict resolution [22]; (III) problem solving skills and critical thinking [23]; (IV) organisation, prioritisation, and time management [24], and (V) stress management $[25,26]$. In most cases, the scope of expected skills presented above requires a high level of social skills from a graduate.

The present authors' assessment of the social skills profile for a selected year of Bachelor's degree graduates in nursing at Medical University of Warsaw showed a very low level of these skills in two dimensions: cooperative skills and social resourcefulness. Cooperative skills that are associated with interpersonal skills enabling cooperation with others, motivating them, providing help and support, as well as mitigating conflicts are crucial for the development of the skills that are particularly expected by employers $[20,22,23]$. The correlation analysis also demonstrated that the age of a graduate was significantly correlated with the level of these skills. Thus, it can be assumed 
that students who are starting to study nursing immediatley after graduating from secondary school were much less prepared in terms of cooperative skills compared to older students. However, none of the admission criteria was a significant predictor of the level of these skills. A psychometric study showed that cooperative skills were highly correlated with the intensity of social training, which gave grounds for the conclusion that they were considerably dependent on appropriate social experiences and susceptible to actions aimed at improvement of those skills. Furthermore, the scale of assessment of these skills was strongly correlated with conscientiousness, which influences the effectiveness of cooperation, providing help and mediation. Therefore, persons with high cooperative skills are particularly welcomed to positions focused on teamwork or care and service activities, which is compliant with the description of professional duties of a nurse [7]. A lack of an apt assessment of these skills during the admission procedure and a very low level of these skills represented by the study group of graduates may raise understandable concerns.

The available literature has demonstrated that nurses with an insufficient level of communicative skills (both oral and written) reported an elevated level of stress that is partly caused by difficulties in contact with therapy team members [21, 23, 27, 28]. Study results have also shown that a low level of these skills negatively affects interpersonal relationships between nurses and doctors and patients, and this may increase the number of conflicts and errors in reports on nursing care [29, 30]. However, Casey et al. observed that communicative skills and the ability to give orders improve significantly within the first 6 months of a newly employed nurse starting work, for whom this job is the first one after graduation [27]. Good results in this regard were also obtained after introducing a mentorship programme at departments employing new nurses, which would provide them with support from a mentor within the first months of work [31]. This allows for the assumption that social skills of MUW graduates concerning cooperation need to be greatly strengthened, which should be reflected in the nursing curriculum and teaching methods used during the course of studies. There is a need for further observation of the role of these skills in graduates who, after graduating from a bachelor's degree programme, start work and/or continue their education on a master's degree programme.

Social resourcefulness was the other domain of the social skills profile that was evaluated very poorly. Also, in this case, no significant correlation was found between any of the admission criteria for the nursing programme and the level of the skills. Social resourcefulness refers to the abilities necessary to deal with various personal issues. Persons with high scores on the scale measuring these competencies are well skilled in obtaining different things from others and are treated favourably or are on preferential terms. These skills might be particularly useful to persons who perform administrative and management duties in their professional practice [6-8]. Hence, it may seem that social resourcefulness is not as important in nursing practice as it is in the case of cooperative skills. However, literature has shown that management-related skills are of great use to nurses because they facilitate planning, setting priorities, and time management $[21,25,28,32]$. A lack of those skills has a particularly strong impact on the level of stress and work efficiency, and it increases the risk of burnout syndrome [20]. There is also evidence that a lack of ability to set priorities directly affects the level of patient safety [33, 34]. Goode et al. emphasised that a development of time management skills is one of the key elements of effective and safe nursing practice. Thus, there is a strong need to increase the level of those skills both during the course of studies and later in professional practice [24]. The same is true in the case of dealing with stress because extending the powers and duties of nurses resulted in increasing their professional liability, which naturally generates a higher level of stress [25]. Knowledge of stress reduction techniques may lead to a significant improvement of the situation of newly employed nurses, lowering the risk of professional failure [26]. In conclusion, it may be stated that social resourcefulness is such an important element of taking up nursing practice effectively that a low level of this skill observed among the group of graduates could significantly affect their success on the labour market.

Community-focused skills that refer to the ability to initiate and meet social aims and engage other people in those actions produced the best results evaluated with the use of the PROKOS questionnaire. The correlation analysis also demonstrated that there was a correlation between the level of these skills among the graduates and the matura exam results in Polish obtained by candidates for studies. Communityfocused skills are strongly related to the intensity of social training, but they do not correlate with the ability to feel empathy, i.e. understand and recognise the emotions of other people. It seems that the development of such skills depends on the system of values and conviction about the importance of social objectives [7]. High community-focused skills are particularly useful to social activists, people working in organisations serving the public good, e.g. charity, which, in a sense, concerns nurses as well [8].

Similarly to the community-focused skills, there was a significant correlation between the level of assertiveness among the graduates and the matura exam results in Polish obtained by candidates for studies. These skills include mainly the ability to give instructions, express disapproval, communicate massages that 
could be unpleasant to others, and oppose a negative course of events [7]. Thus, these skills are crucial for nurses, and they directly influence the quality of patient care [20]. It was found that assertive skills were positively related to the need of perseverance that leads to results in pursuing goals. It was also observed that there was a negative correlation between assertive skills and the need to take care of others, which may be indicative of the fact that assertive skills do not correlate with overindulgence towards others when meeting goals is at stake. Additionally, these skills were also correlated with interests in such activities that involve people-to-people contact, and particularly interests related to management and organisational issues [8]. Such a description allows for the presumption that persons with high levels of skills of this kind should be managers, team leaders, organisers, and administrators in their professional practice. Nurses who would like to progress on the career ladder should develop their assertive skills [20, 21].

Abilities related to dealing with social situations and being the centre of attention constituted the last element of the social skills profile assessed in the present study. These skills develop when a person is fascinated with exposing themselves in public and striving for recognition [7]. A predictive analysis demonstrated a strong correlation between a high level of sociable skills of graduates in nursing and scores achieved by candidates for additional subjects. However, a comparison of the level of social skills according to a selected subject in the admission procedure did not show statistically significant differences. Sociable skills are very useful to persons who professionally organise various events such as integration trips, training, marketing actions, and those whose job involves making public speeches or maintaining relations with the media [6-8]. With reference to the profession of nursing, it seems that the scope of these skills does not constitute the most important resource of skills necessary to perform professional tasks effectively. However, there is a group of persons who may be predisposed to be a leader due to their leadership skills. Thus, nurses with such abilities may effectively represent their occupational group both on the local and national levels, particularly if they also have a high level of assertiveness.

\section{Conclusions}

Admission criteria used in the selection procedure for nursing insufficiently predict the level of future social skills of graduates. It is recommended that assessment of non-cognitive skills at the stage of recruiting candidates be introduced, to increase the validity of the admission procedure with respect to initial social skills. It is necessary to increase efforts to improve the curriculum of the nursing programme so that it includes the teaching of social skills, particularly those related to cooperation and assertiveness, to a greater extent than it does at present. Specific and validated tools of educational measurement should be included in order to properly monitor educational progress of nursing students with respect to teaching social skills.

\section{Conflict of interest}

The authors declare no conflict of interest.

\section{References}

1. White RW. Motivation reconsidered: the concept of competence. Psychol Rev 1959; 66: 297-333.

2. Waters E, Sroufe LA. Social competence as a developmental construct. Dev Rev 1983; 3: 79-97.

3. Nęcka E. Inteligencja. Geneza - struktura - funkcje. Gdańskie Wydawnictwo Psychologiczne, Gdańsk 2003.

4. Rabiasz R, Kachaniuk H. Skala pielęgniarskich kompetencji społecznych. Piel XXI 2015; 50: 22-27.

5. Rozporządzenie Ministra Nauki i Szkolnictwa Wyższego z dnia 9 maja 2012 r. w sprawie standardów kształcenia dla kierunków studiów: lekarskiego, lekarsko-dentystycznego, farmacji, pielęgniarstwa i położnictwa (Dz.U. $2012 \mathrm{nr} 0$ poz. 631).

6. Martowska K. Model uwarunkowań kompetencji społecznych. [In:] Kompetencje społeczne w kierowaniu i dowodzeniu Siłami Zbrojnymi RP. Skrabacz A, Gutowski J (eds.). Wojskowe Centrum Edukacji Obywatelskiej, Warsaw 2015.

7. Martowska K, Matczak A. Pomiar kompetencji społecznych - prezentacja nowego narzędzia diagnostycznego. Psychol Jako Życia 2013; 12: 43-56.

8. Matczak A, Martowska K. Profil Kompetencji Społecznych PROKOS. Podręcznik. Pracownia Testów Psychologicznych Polskiego Towarzystwa Psychologicznego, Warsaw 2013

9. Pitt V, Powis D, Levett-Jones T, Hunter S. The influence of personal qualities on performance and progression in a pre-registration nursing programme. Nurse Educ Today 2014; 34: 866-871.

10. Schmidt B, MacWilliams B. Admission criteria for undergraduate nursing programs: a systematic review. Nurse Educ 2011; 36: 171-174.

11. Altmiller G. Student perceptions of incivility in nursing education: implications for educators. Nurs Educ Perspect 2012; 33: 15-20.

12. Luhanga F, Yonge O, Myrick F. Hallmarks of unsafe practice: what preceptors know. J Nurses Staff Dev 2008; 24: 257-264.

13. Pitt V, Powis D, Levett-Jones T, Hunter S. Nursing students' personal qualities: a descriptive study. Nurse Educ Today 2014; 34: 1196-1200.

14. Panczyk M, Zarzeka A, Belowska J, Gotlib J. Risk of attrition from Bachelor's degree of Nursing programme - predictive evaluation. Piel XXI 2015; 51: 66-72.

15. Osuch W. Kompetencje w zakresie komunikacji interpersonalnej w dobie postępujących procesów globalizacji. Przed Edu 2011; 7: 333-346.

16. Rutkowska K. Kompetencje społeczne - bufor wypalenia zawodowego pielęgniarek. Med Ogol Nau Zdro 2012; 18: 319-323. 
17. Kimak K. Sylwetka współczesnej pielegnniarki a hasło uczelni: prawda, dobro, skuteczność. Zarzadz Edu 2012; 84: 151-174.

18. Chant $\mathrm{S}$, Jenkinson T, Randle J, Russell G. Communication skills: some problems in nursing education and practice. J Clin Nurs 2002; 11: 12-21.

19. Bhana VM. Interpersonal skills development in Generation Y student nurses: a literature review. Nurse Educ Today 2014; 34: 1430-1434.

20. Theisen JL, Sandau KE. Competency of new graduate nurses: a review of their weaknesses and strategies for success. J Contin Educ Nurs 2013; 44: 406-414.

21. Hickey MT. Preceptor perceptions of new graduate nurse readiness for practice. J Nurses Staff Dev 2009; 25: 35-41.

22. Wangensteen S, Johansson IS, Nordstrom G. The first year as a graduate nurse: an experience of growth and development. J Clin Nurs 2008; 17: 1877-1885.

23. Dyess SM, Sherman RO. The first year of practice: new graduate nurses' transition and learning needs. J Contin Educ Nurs 2009; 40: 403-410.

24. Goode CJ, Lynn MR, Krsek C, Bednash GD. Nurse residency programs: an essential requirement for nursing. Nurs Econ 2009; 27: 142-147.

25. Poynton MR, Madden C, Bowers R, Keefe M. Nurse residency program implementation: the Utah experience. J Healthc Manag 2007; 52: 385-396.

26. Romyn DM, Linton N, Giblin C, Hendrickson B, Limacher LH, Murray C, Nordstrom P, Thauberger G, Vosburgh D, Vye-Rogers L, Weidner A, Zimmel CM. Successful transition of the new graduate nurse. Int J Nurs Educ Scholarsh 2009; 6: Article 34.

27. Casey K, Fink R, Krugman M, Propst J. The graduate nurse experience. J Nurs Adm 2004; 34: 303-311.

28. Fink R, Krugman M, Casey K, Goode C. The graduate nurse experience: qualitative residency program outcomes. J Nurs Adm 2008; 38: 341-348.

29. Hartigan I, Murphy S, Flynn AV, Walshe N. Acute nursing episodes which challenge graduate's competence: perceptions of registered nurses. Nurse Educ Pract 2010; 10: 291-297.

30. Olson ME. The "millennials": first year in practice. Nurs Outlook 2009; 57: 10-17.

31. Komaratat S, Oumtanee A. Using a mentorship model to prepare newly graduated nurses for competency. J Contin Educ Nurs 2009; 40: 475-480.

32. Morrow S. New graduate transitions: leaving the nest, joining the flight. J Nurs Manag 2009; 17: 278-287.

33. Fero LJ, Witsberger CM, Wesmiller SW, Zullo TG, Hoffman LA. Critical thinking ability of new graduate and experienced nurses. J Adv Nurs 2009; 65: 139-148.

34. Wolff AC, Regan S, Pesut B, Black J. Ready for what? An exploration of the meaning of new graduate nurses' readiness for practice. Int J Nurs Educ Scholarsh 2010; 7: Article7.

\section{Address for correspondence:}

Mariusz Panczyk PhD, PharmD, Assoc. Prof.

Division of Teaching and Outcomes of Education

Faculty of Health Science

Medical University of Warsaw

ul. Żwirki i Wigury 61, 02-091 Warsaw, Poland

Phone: +48 22520490

Fax: +48 225720491

E-mail: mariusz.panczyk@wum.edu.pl 